\title{
QUEEN'S
UNIVERSITY
BELFAST
}

\section{Using microbiological tracers to assess the impact of winter land use restrictions on the quality of stream headwaters in a small catchment.}

Flynn, R. M., Deakin, J., Archbold, M., Cushnan, H., Kilroy, K., O'Flaherty, V., \& Misstear, B. D. (2016). Using microbiological tracers to assess the impact of winter land use restrictions on the quality of stream headwaters in a small catchment. Science of the Total Environment, 541, 949-956.

https://doi.org/10.1016/j.scitotenv.2015.09.071

Published in:

Science of the Total Environment

Document Version:

Peer reviewed version

Queen's University Belfast - Research Portal:

Link to publication record in Queen's University Belfast Research Portal

Publisher rights

(c) Elsevier Ltd 2015. This manuscript version is made available under the CC-BY-NC-ND 4.0 license http://creativecommons.org/licenses/by$\mathrm{nc}-\mathrm{nd} / 4.0 /$ which permits distribution and reproduction for non-commercial purposes, provided the author and source are cited.

\section{General rights}

Copyright for the publications made accessible via the Queen's University Belfast Research Portal is retained by the author(s) and / or other copyright owners and it is a condition of accessing these publications that users recognise and abide by the legal requirements associated with these rights.

Take down policy

The Research Portal is Queen's institutional repository that provides access to Queen's research output. Every effort has been made to ensure that content in the Research Portal does not infringe any person's rights, or applicable UK laws. If you discover content in the Research Portal that you believe breaches copyright or violates any law, please contact openaccess@qub.ac.uk. 


\title{
Using microbiological tracers to assess the impact of winter land use restrictions on the quality of stream headwaters in a small catchment
}

Raymond M.Flynn ${ }^{* 1}$, Jenny Deakin ${ }^{2,4}$, Marie Archbold ${ }^{1,2}$, Hugh Cushnan ${ }^{1}$, Kate Kilroy ${ }^{3}$, Vincent O’Flaherty $^{3}$ and Bruce D. Misstear ${ }^{4}$.

1. School of Planning, Architecture and Civil Engineering, The Queen's University of Belfast, David Keir Building, Stranmillis Road, Belfast BT9 5AG, Northern Ireland.

2. Now at Environmental Protection Agency, Richview, Clonskeagh, Dublin 14, Ireland.

3. Microbiology, School of Natural Sciences and Ryan Institute, NUI, Galway, University Road Galway, Ireland

4. Department of Civil, Structural and Environmental Engineering, Trinity College Dublin, Dublin 2, Ireland

*Corresponding author. E-mail r.flynn@qub.ac.uk. Tel +44 2890974044.

Key Words

Water Quality; Hydrological Pathways; Pathogenic Microorganisms; Microbial Source Tracking; Seasonality.

\begin{abstract}
Diverse land use activities can elevate risk of microbiological contamination entering stream headwaters. Spatially distributed water quality monitoring carried out across a $17 \mathrm{~km}^{2}$ agricultural catchment aimed to characterize microbiological contamination reaching surface water and investigate whether winter agricultural land use restrictions proved effective in addressing water quality degradation. Combined flow and concentration data revealed no significant difference in fecal indicator organism (FIO) fluxes in base flow samples collected during the open and prohibited periods for spreading organic fertilizer, while relative concentrations of E.coli, fecal streptococci and sulfite reducing bacteria indicated consistently fresh fecal pollution reached aquatic receptors during both periods. Microbial source tracking, employing Bacteroides 16S rRNA gene markers, demonstrated a dominance of bovine fecal waste in river water samples upstream of a wastewater treatment plant discharge during open periods. This contrasted with responses during prohibited periods where human-derived signatures dominated. Differences in microbiological signature, when viewed with hydrological data, suggested that increasing groundwater levels restricted vertical infiltration of effluent from on-site wastewater treatment systems and diverted it to drains and surface water. Study results reflect seasonality of contaminant inputs, while suggesting winter land use restrictions can be effective in limiting impacts of agricultural wastes to base flow water quality. (200 words)
\end{abstract}




\section{Introduction}

That hydrological processes in stream headwaters influence the water quality and discharge regimes further downstream has been recognized for some time (Alexander et al., 2007). Although initial studies focused on processes operating in upland catchments where pollution pressures are lower, a large number of rivers and streams across Ireland have headwaters in more intensively cultivated lowland areas with greater water pollution pressures. These pressures have the potential to impact water quality, which in turn can pose a threat to aquatic ecological health and/or drinking water supplies (Archbold et al., 2010).

Pathogenic microorganisms (pathogens), such as pathogenic bacteria, viruses and parasitic protozoans, display a particularly high capacity to impact drinking water. Their widespread occurrence and high source concentrations, coupled with their ability to cause illness at low doses, means small quantities of pathogen-bearing wastes can render large volumes of water unfit for human consumption (Mara and Horan, 2003). As a consequence the raw quality of surface waters in many Irish catchments displays potential to affect human health, either through consumption of water and/or contaminated foodstuffs, e.g. shellfish in receiving coastal waters (Whyte et al., 2004).

Surface water acts as the principal source of drinking water across much of the European Union (EU), as well as for over $80 \%$ of the population of Ireland (EPA, 2015). Although most potable water in Ireland is provided through large public water supplies, a significant proportion of the population is served by smaller public networks, or private supplies, where water may receive more limited treatment prior to provision to end users, thus elevating risk of exposure. Routine water quality monitoring provides a basis for assessing contamination risks. However, analyzing for pathogenic microorganisms can prove expensive, time consuming and inconclusive (Pepper et al., 2011). As a consequence, microbiological water quality monitoring focuses on more robust fecal indicator organisms (FIOs), which are easier to analyze (Mara and Horan, 2003). More recently, microbial source tracking (MST) has further assisted in determining the origin of FIOs detected in water supplies (Seurinck et al., 2005). In Ireland a library-independent method, developed by Kildare et al. (2007) , has permitted its application to typical environmental settings and has designed host-specific qPCR assays based on the order Bacteroidales. Since this bacterial group are more prevalent in the gastrointestinal tract than the FIOs, and make up approximately one-third of the human faecal microflora (Noble et al., 2006), qPCR assays targeting variable regions of the Bacteroidales 16S rRNA gene allow for the discrimination between human and ruminant sources of faecal pollution.

Despite their widespread occurrence and potential to impact health, natural attenuation processes such as inactivation (loss of infective capacity), reduce intestinal bacteria concentrations when they exit their hosts (Mara and Horan, 2003). Attenuation rates vary depending on microorganism type and ambient environmental conditions (Pepper et al., 2011). Although these processes serve to reduce risks to human health, recent Irish Environmental Protection Agency (EPA) drinking water reports have noted that microbiological contaminants, as reflected by the presence/absence of Escherichia coli (E.coli), remain the principal threat to water quality across Ireland (EPA, 2015).

The EU Water Framework Directive (WFD) requires member states to protect water resources, and includes for the provision of microbiologically safe drinking water (Directive 2000/60/EC) (EC, 2000). The WFD's requirement to achieve goals in an integrated manner at the catchment scale entails developing an understanding of the nature and distribution contaminant sources and the risks they pose to receptors. The risks posed to catchment water quality by agricultural activities have been recognized by the EU and transposed into law through the Nitrates Directive (Directive 91/676/EEC) (EC, 1991) (subsequently subsumed into the WFD). To address the risk of agricultural pollution of water supplies the WFD requires implementation of land use measures to reduce the risk of contaminant delivery. In the Republic of Ireland this has been addressed through the application of winter farming measures (Government of Ireland, 2014). These measures aim to restrict nutrient application (including organic fertilizer) to farmland during wetter, colder periods of the year when there is little plant growth, and when hydrological processes are more likely to deliver diffuse agricultural pollution to water courses. More specifically the Irish Department of Agricultural, Food 
and the Marine (2014) has implemented prohibited spreading periods (, or a closed season,) when no application of fertilizer is permitted. These periods vary by region across Ireland, but correspond to times when livestock are housed indoors and where organic wastes must be stored (and accumulate) in concentrated areas, most notably farmyards. Poor storage practices can result in farmyards acting as point sources for agricultural contaminants, particularly during prolonged wet periods (Department of Food, Agriculture and the Marine, 2014). Conversely, appropriate storage practices can prevent wastes from reaching water courses, thus reducing pollutant loads that may potentially impact drinking water supplies.

In Irish rural settings, characterizing the impacts of agricultural practices on water quality can be complicated by the widespread occurrence of additional pollutant sources, including on-site wastewater treatment systems (OSWWTS), mainly septic tanks (Arnscheidt et al. , 2007). Although these systems have been demonstrated as effective technologies for wastewater treatment in free draining Irish subsoils ((Keegan et al., 2014), their efficiency in lower permeability deposits where high water tables limit treatment capacity, including the removal of FIOs, have proved more questionable (Donohue et al., 2015). Characterizing attenuation processes associated with OSWWTSs has proved particularly challenging in geologically heterogeneous catchments, where highly variable subsoil cover complicates characterization of the capacity of the ground to accept percolating effluent for part or all of the year. Where ranges of groundwater fluctuation prove substantial, this may result in intermittent direct discharge to the surface, potentially resulting in significantly reduced levels of effluent treatment before reaching aquatic receptors (Donohue et al., 2015).

Assessing the impact of land use control measures and distinguishing the effects of agriculturallyderived microbiological contaminants from other sources at the catchment scale proves challenging, particularly in those catchments underlain by aquifers classed as poorly productive (based on their limited aquifer transmissivity and storativity, along with the low well yields obtained from them), which underlie over 65\% of Ireland (Moe et al., 2010). High spatial and temporal variations in transmissivity (due to significant water table fluctuations in low storage media) can potentially influence those hydrological pathways delivering pollutants to aquatic receptors across a catchment at different times of the year. Focused water quality monitoring assists considerably in characterizing these impacts at the catchment (drainage basin) scale (Archbold et al., 2010). However, failure to characterize hydrological conditions during sampling can result in ambiguity or incorrect interpretation. Conversely, significant synergies can be achieved by combining water quality data with hydrological datasets (rainfall, discharge rates, water levels) to better understand nutrient delivery mechanisms and catchment-scale export of contaminants (Kay et al., 2010).

This article describes an integrated program of hydrological and microbiological water quality monitoring implemented across a geologically heterogeneous catchment, underlain by poorly productive and locally productive bedrock aquifers, and covered by variable thicknesses of subsoil. Monitoring over a one year period aimed to investigate the impacts of a range of anthropogenic activities that could affect the microbiological quality of surface water. More specifically, spatially distributed conventional microbiological water quality monitoring, coupled with a program of MST and measurements of surface water discharge provide a basis for improved characterization of contaminant delivery mechanisms and contaminant sources.

\section{Methodology}

Site setting

The $17 \mathrm{~km}^{2}$ Mattock River Catchment straddles the border between County Louth and County Meath in the Republic of Ireland (Figure 1). The Mattock's $6.6 \mathrm{~km}$ long river channel drains an area at between 251 meters above mean sea-level (mAMSL) and 85 mAMSL, with 83\% of land used for pasture (dairy and beef cattle) and 7\% used for arable agriculture (Deakin et al., 2015). Remaining areas are dominated by undeveloped scrub/woodland and an urban area in the vicinity of Collon Town (Figure 1). Silurian greywackes and shales, which are classed as a poorly productive aquifer, extend 
from the river's headwaters to approximately three km downstream where they come into faulted contact with a more (locally) productive Ordovician volcanic and metasedimentary aquifer; Silurian greywackes and shales once again underlie the lowest $1 / 6^{\text {th }}$ of the catchment. Despite the contrast in bedrock geology, spot gauging showed flow to increase in an approximately linear manner between the stream headwaters and the catchment outlet during the winter and early spring period (Deakin et al., 2015).

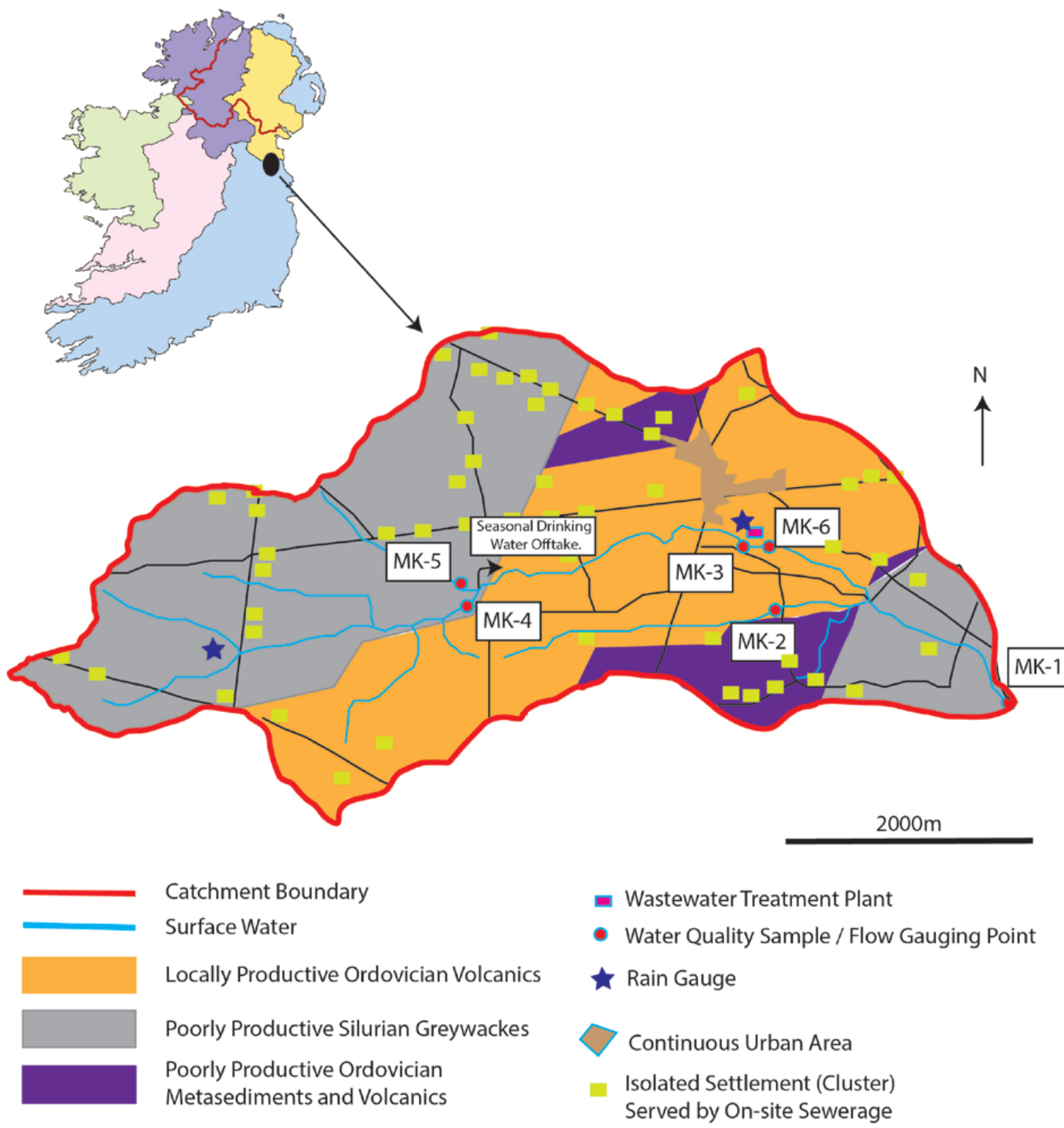

Figure 1: Location Map for the Mattock Catchment, Republic of Ireland, showing the principal bedrock hydrogeological units, the location of monitoring infrastructure and potential sources of human sewage.

Low permeability glacial till subsoils underlie most of the catchment, with thicknesses generally increasing toward the lower lying areas (See Supporting Information \#1). Areas with moderate to thick sequences of till are drained by an extensive network of field drains that discharge to the river; the drains display variable levels of saturation and hydraulic connectivity with the river during the year. Water level records in a monitoring well, set in the subsoil and close to the catchment outlet 
(MK-1), reveal a close correspondence in trends with river stage. However, these trends are less clearly defined in deeper piezometers at the same location.

Approximately half of the Mattock Catchment's population of 1850 lives in the town of Colon, Co. Louth, approximately $2 \mathrm{~km}$ upstream from the catchment outlet. The wastewater treatment plant serving the town discharges to the river, where it makes intermittent contributions to flow between MK-3 and MK-6. Elsewhere in the catchment the population is served by onsite wastewater treatment systems (Figure 1).

Continuous monitoring of discharge at the catchment outlet (MK-1) between February 2011 and February 2013 showed flow to vary from $15 \mathrm{~m}^{3} / \mathrm{sec}$ down to $0.002 \mathrm{~m}^{3} / \mathrm{sec}$, although summer low flows at the catchment outlet were influenced by summer drinking water abstractions at a point approximately $4 \mathrm{~km}$ upstream; this often stopped flow from the uppermost $43 \%$ of the catchment from continuing downstream. Average flow in the river over the monitoring period was $0.14 \mathrm{~m}^{3} / \mathrm{sec}$.

Annual rainfall of $901 \mathrm{~mm} / \mathrm{yr}$. fell roughly evenly throughout the year, of which $417 \mathrm{~mm} / \mathrm{yr}$. was hydrologically effective rainfall (i.e. the balance between total rainfall less actual evapotranspiration). Detailed investigations of near surface hydrological processes in the vicinity of the Mattock's source, revealed that overland flow could occur in response to heavy rainfall and elevated groundwater levels in subsoils (saturation excess overland flow); this overland flow, and active flow in ephemeral drains, occurs predominantly during winter when evapotranspiration proved negligible (Deakin 2015).

Longitudinal channel profiling by Finn (2012) revealed a gradual rise in specific electrical conductance (SEC) moving from stream headwaters to the catchment outlet; the study also noted peaks in SEC at locations where cattle were able to access the stream and gross contamination by livestock wastes was observed. Although individual spikes/troughs had limited impact on overall SEC levels along the river's course, their collective effect gave rise to a gradual increase in SEC moving downstream, reflecting a gradual increase in total dissolved solids content in the river's water (Finn, 2012).

\section{$\underline{\text { Sampling and Analyses }}$}

A program of monitoring, implemented between December 2011 and December 2012 focused on characterizing the impact of winter agricultural land use restrictions on the microbiological quality of surface water. Monitoring points, located along the length of the river, aimed to examine spatial variations in water quality during open periods (when livestock could graze outdoors and when organic fertilizers could be applied, namely mid-February to mid-October), and when these activities were prohibited, i.e. mid October to mid-February.

Sample collection (approximately monthly) for fecal indicator organisms (FIOs) focused on dry periods, ideally more than five days after the most recent rainfall, to provide an indication of the impacts of pollutant inputs during quiescent hydrological periods. However, logistical time constraints on sample collection and analysis meant that this could not always be achieved, particularly during the open period, due to wetter-than-usual conditions encountered during the summer of 2012. All monitoring was accompanied by flow gauging to provide snap shots of microorganism fluxes along the length of the river. Flow at the seasonal drinking water off take, wastewater treatment plant (Figure 1) and catchment outlet were monitored continuously using Orpheus Mini stage loggers (Ott Hydrometry, Sheffield). Where continuous measurement devices proved unavailable, flows were determined from staff gauges and associated rating curves, generated with data collected using a handheld flow meter (Herschy, 1999). Rain gauges at the stream headwaters, where Deakin (2015) investigated overland flow mechanisms at the plot scale, and at the Collon Wastewater Treatment Plant, provided a continuous record of rainfall during the monitoring period. Routine observations of selected drains across the catchment noted their extent of saturation/hydraulic connectivity throughout the year.

Samples collected for microbiological analyses in one liter uPCV sterile bottles, were immediately chilled to four Degrees C, before delivery to the Microbiological Laboratory of the Agriculture Food 
and Biosciences Institute (AFBI), Belfast, to initiate analyses within 12 hours of sampling. Sample analyses consisted of a standard suite of FIO parameters, namely Total Viable Counts at 22 Degrees C, Total Viable Counts at 37 Degrees C, Total Coliforms, E.coli, Enterococci and sulfite reducing bacteria. Results of these conventional analyses provided a suite of data that permitted comparison against results of water quality analyses collected in similar settings in which fecal source conditions, most notably age, were well characterized. Sample analyses by conventional plating and incubation methods adhered to protocols described in Standing Committee of Analysts Blue Books (UK Environment Agency, 2014), with all samples analyzed in triplicate.

A more limited program of MST aimed to further investigate the source of the microbiological contaminants across both catchments. Sample collection, carried out at routine FIO sampling points on two occasions, toward the end of the open season (October 2012) and during the closed season (December 2012), provided a basis for investigating whether land use restrictions influenced the origin of microbiological contamination entering water courses at different times of the year. Triplicate one liter grab samples were retrieved from each monitoring point and transported to the Microbiology Department at NUI Galway on ice and stored at four Degrees C before filtration. Triplicate samples were filtered onto two micron pore size cellulose nitrate filters (Whatman) $47 \mathrm{~mm}$ diameter.

\section{Molecular Analysis}

Molecular markers, based on host-specific Bacteroidales bacteria for universal, human and ruminantderived faecal matter, were employed to determine target occurrence using quantitative Polymerase Chain Reaction (qPCR) assays. Total genomic DNA was extracted from respective filters as described previously in Barrett et al. (2013). MST qPCR assay conditions were identical to those described by Kildare et al. (2007). (Primers and probes used for these assays are outlined in Supplemental Material \#2, namely human-specific (BacHum) and ruminant-specific (BacBov) Bacteroidales markers.) E. coli colonies containing cloned target sequences were sent as a gift to the MEL laboratory from University of California, Davis. Plasmids containing cloned target sequences were used as standards in the quantitative assay. QPCR analysis was performed on triplicate samples using a Light Cycler 480 (Roche, Mannheim, Germany) in duplicate.

Sample analysis by library-independent polymerase chain reaction for the detection of host specific 16S RNA gene abundance aimed to distinguish between human and bovine sources of fecal waste, using real time assays designed by Kildare et al.(2007). These assays target regions of the Bacteroidales bacteria that are specific to human (BacHum) and cow (BacCow) fecal material. Total genomic DNA extraction followed the protocol of Barrett et al. (2013) with assay conditions for quantitative PCR (qPCR) carried out following the protocol of Kildare et al. (2007)

\section{Results}

Discharge measured at the Mattock catchment outlet (MK-1) responded strongly to rainfall throughout the year. However, base flow in the summer period was lower than other times of the year, in part as a consequence of drinking water abstractions at the offtake approximately $3 \mathrm{~km}$ upstream (Figure 1). These abstractions operated between the beginning of June 2012 and end of September 2012. Following this period the river's hydrograph was unaffected by drinking water abstractions. 
From the beginning of October 2012 to the end of the year the hydrograph generated for the Mattock continued to display a characteristic flashy response to rainfall, as is typically observed in catchments underlain by poorly productive bedrock aquifers and low permeability soils \& subsoils (Figure 2).

Over the same period a notable increase in base flow became apparent. This increase corresponds to increased groundwater levels, as observed in the subsoil monitoring well at the catchment outlet. It is noteworthy that the location of this well lies within $50 \mathrm{~m}$ of the river (and approximately $500 \mathrm{~m}$ from the catchment divide). In addition, a growing number of seasonally waterlogged areas developed during this period, along with increased hydraulic connectivity in open drains.

\section{Plots of (a) Discharge, Rainfall and (b) Groundwater head \\ in MK-1S, Mattock Catchment, Autumn 2012. (Inverted Triangles: Microbiological Sampling)}

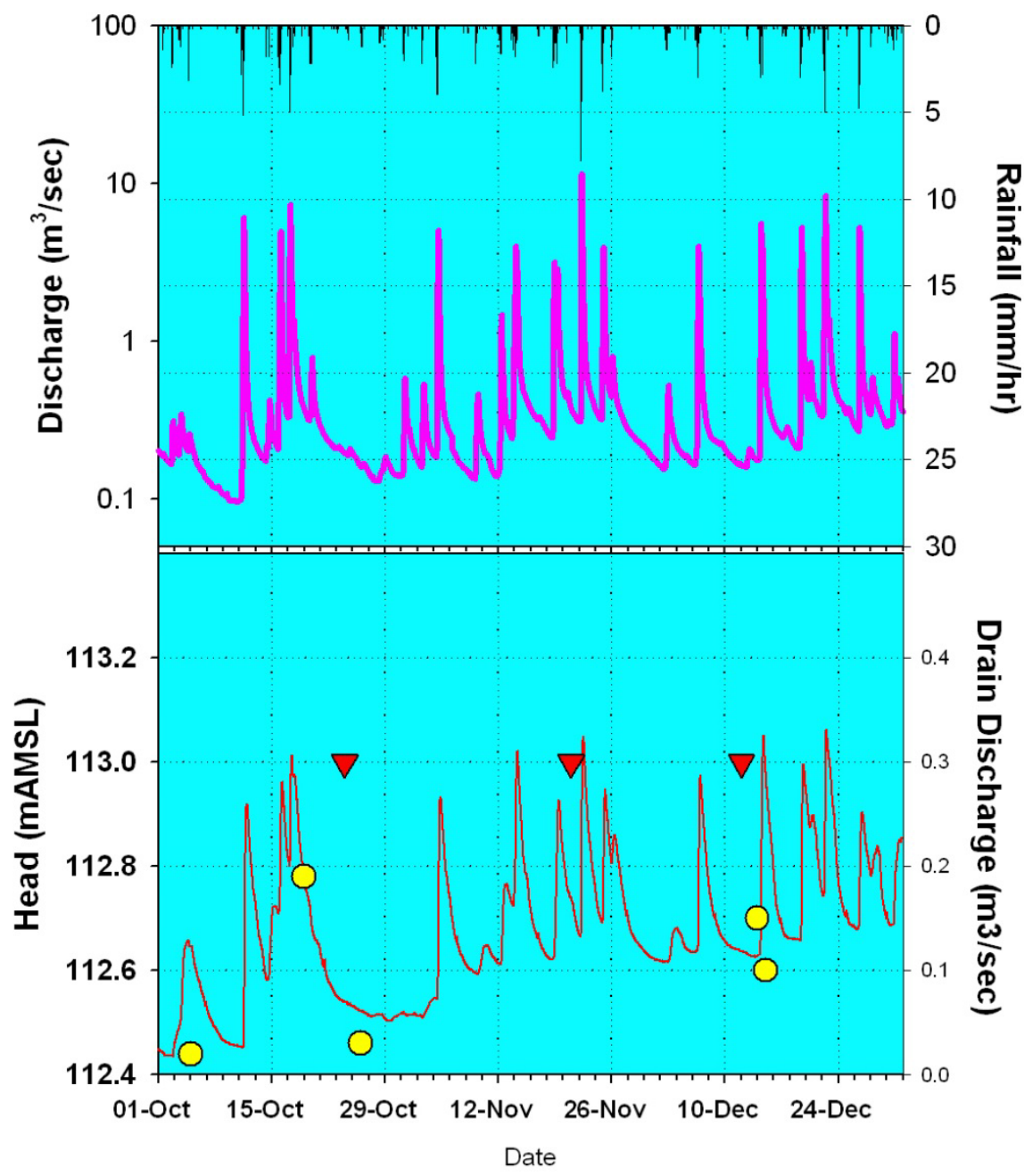

Figure 2: Plot of rainfall and Mattock River discharge (above) and groundwater level at the subsoil borehole MK-1S for the period from $1^{\text {st }}$ October to $31^{\text {st }}$ December 2012. Inverted triangles reflect microbiological water quality sampling times across the catchment. Circles reflect discharge rates determined from spot measurements of drain flow in a drain in the vicinity of the Mattock River headwaters. Open season samples were collected at the start of October 2012. Closed season samples were collected in December 2012.

Figure 3 summarizes results combining FIO concentration data and river discharge data to reflect the variation in microorganism fluxes across the catchment during open and closed period monitoring. Data suggest an increase in total coliform and E.coli fluxes moving downstream, when comparing sampling points closer to the head waters (MK-4 and MK-5) with data collected at the catchment 
outlet (MK-1), as the contributing areas (subcatchment) for each sampling point increases. (Note that MK-2 is a sampling point on a tributary to the main river.) By contrast differences in concentrations in samples collected from immediately above the wastewater treatment plant outlet are less definitive. (These may reflect the impacts of drain discharge a short distance upstream and may not reflect complete mixing in the channel). A similar difference is apparent in TVC 22 Degrees $C$ for the same point.

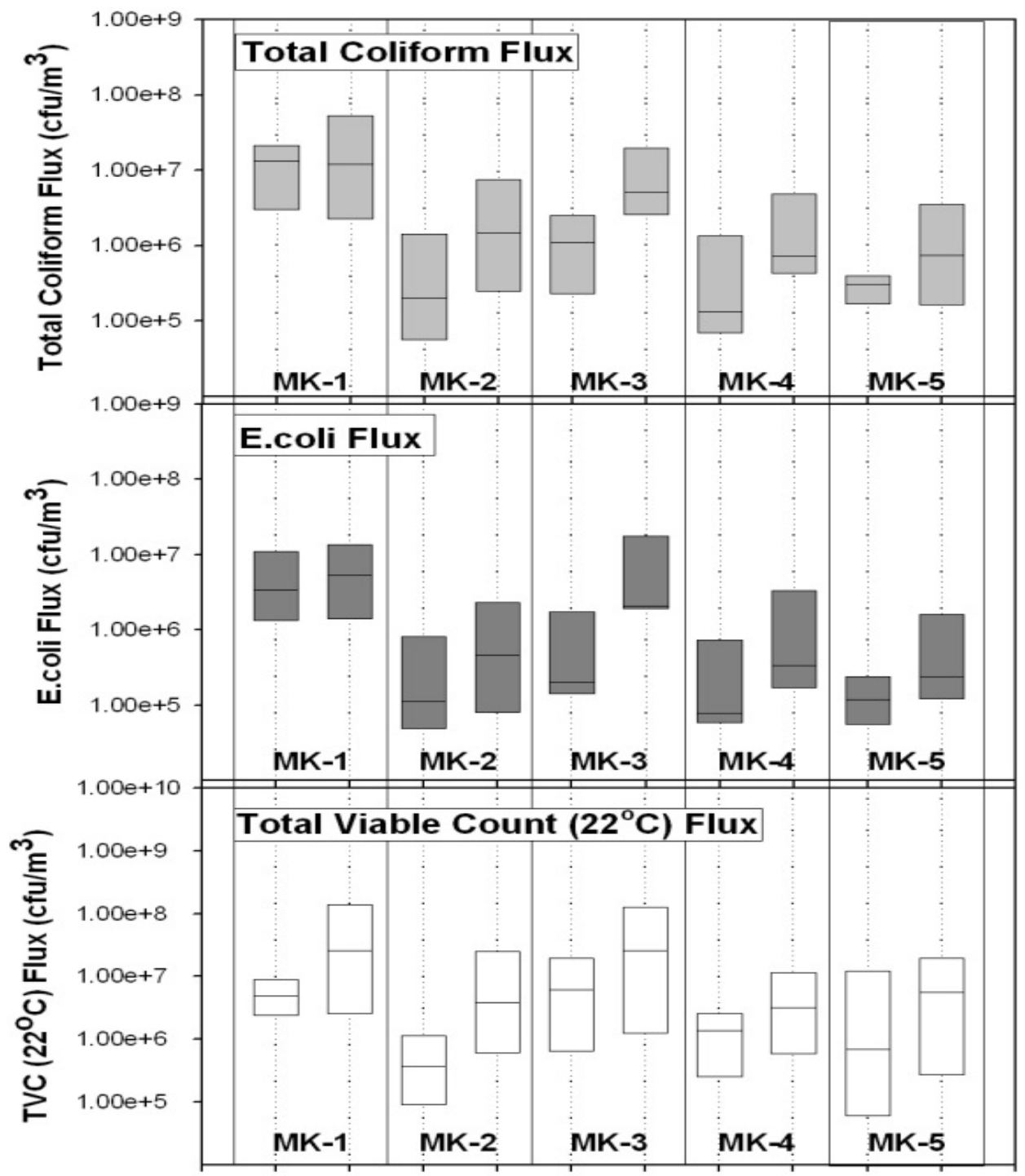

Sampling Point

Figure3: Comparison of fluxes of indicator microorganisms at representative sampling points across the Mattock Catchment. For each monitoring point, results presented on the left hand side summarize findings from samples collected during the open season, while those on the right summarize results from the closed season.

Comparison of FIO fluxes determined from samples collected at individual points during open and closed seasons using Mann Whitney non-parametric U test statistics (5\% significance level) suggest no significant difference in TVC 22 Degrees $C$ at points along the main channel, while results at MK2 indicate greater fluxes in winter, possibly reflecting impacts of soil erosion in the subcatchment. By contrast analyses for Total Coliforms and E.coli suggest no significant difference in summer and winter fluxes at all sampling points, apart from MK-3, where winter levels are higher. 
Trilinear plots provided a means to investigate the changes in relative concentrations the three FIOs with characteristic differences in inactivation rates (E.coli>Enterococci> SRB). Results for open and closed seasons revealed little difference, with data consistently clustering toward the E.coli apex, indicating a fresh source signature (Figure 4). This contrasts with responses observed in base flow samples collected from comparable catchment in Co. Down, Northern Ireland, but with lower densities of OSWWTSs. In that catchment, samples displayed comparable FIO relative concentrations to those observed in Mattock during the open period, but had relative concentrations that were more dominated by sulfite reducing bacteria during the close period (See Supporting Information \#3), indicative of more aged waste.

\section{Enterococci}

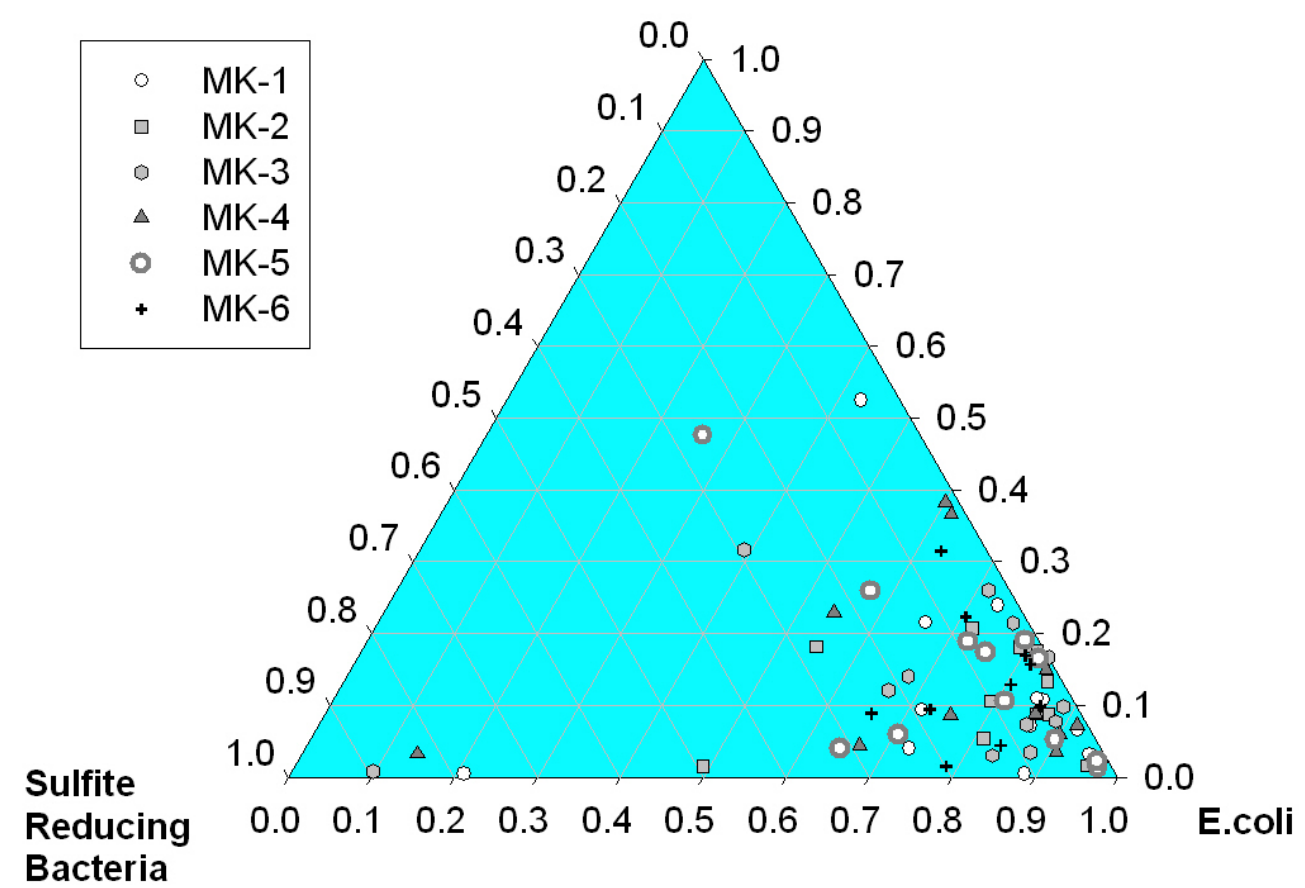

Figure 4: Trilinear plot of representative FIOs with contrasting inactivation rates. The dominance of points clustering at the E.coli apex during all sampling rounds indicates persistent fresh sources of fecal contamination across the catchment throughout the year.

Figure 5 summarizes the results of MST analyses for samples collected in open and closed seasons. Open season (October 2012) samples were positive for the ruminant-specific Bacteroidales bacteria (BacBov) above the Collon wastewater treatment plant outlet; downstream of which both BacBov and human-specific Bacteroidales bacteria (BacHum) were detected. In contrast, closed season samples (December 2012) detected BacHum at all points, but failed to detect BacBov.

\section{Discussion}

The surface water microbiology monitoring program detected fecal indicator microorganisms in all samples collected at all points monitored across the Mattock. This indicates the presence of persistent sources of fecal contamination. A variety of sources distributed around the catchment may be responsible for the contaminant levels observed, including agricultural wastes, OSWWTS effluent and discharge from the Collon Wastewater Treatment Plant.

Examination of FIO fluxes suggest the load of fecal bacteria increases moving downstream from the stream headwaters, with further contributions made between the drinking water offtake and the catchment outlet. This in turn points to multiple sources of contamination. Differences at MK 3 in 
Total Coliform and E.coli levels are less clear cut than elsewhere and may reflect the incomplete mixing of river water with discharge from a drain located a short distance upstream as noted by Finn (2012).

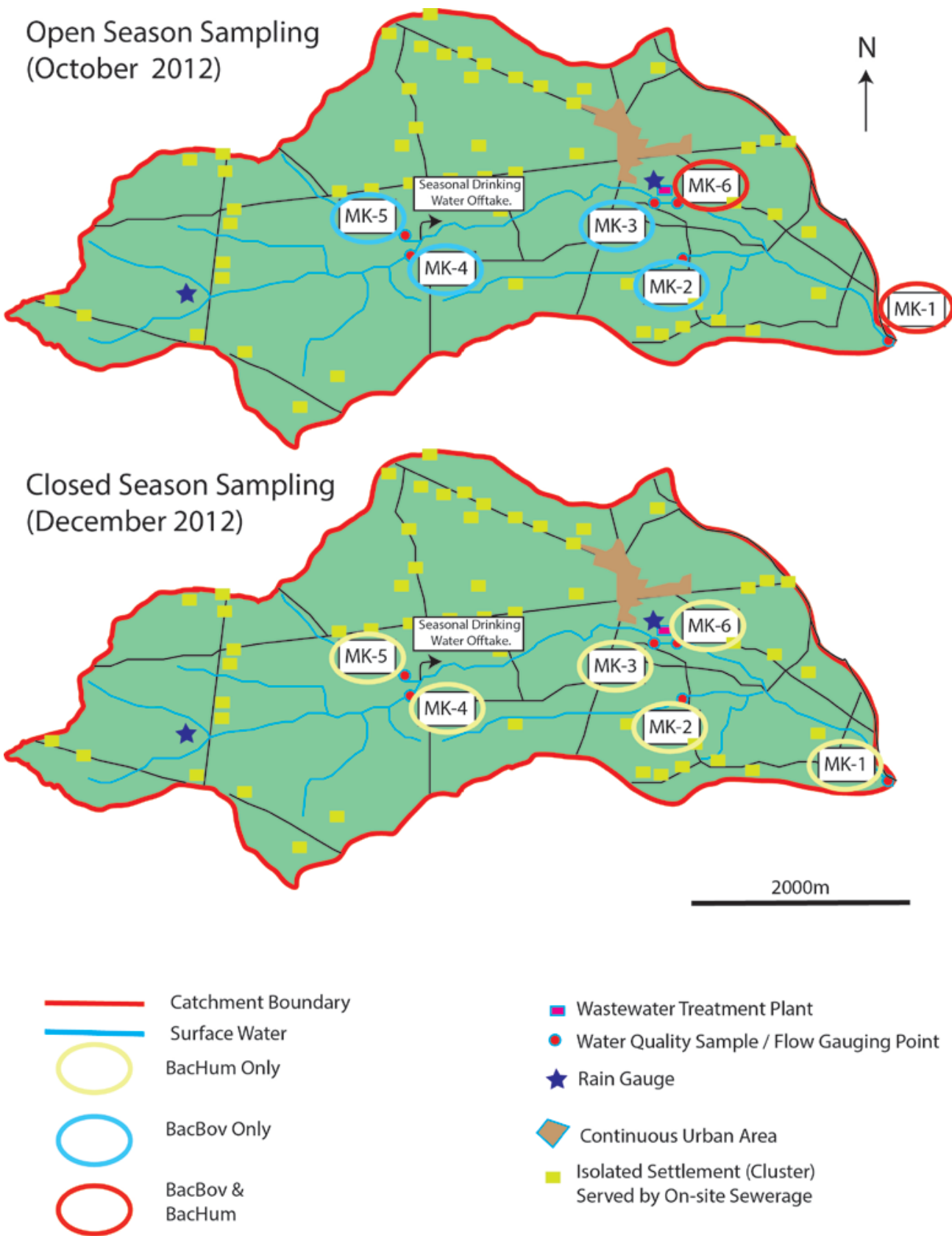

Figure 5: Results of MST analyses, Mattock Catchment, Republic of Ireland. Samples collected during the open season (above) indicate bovine contamination (BacBov) at locations enclosed by blue ellipses and mixed human \& bovine contamination at locations enclosed by red ellipses (BacBov and BacHum). Results of analyses collected during the closed season (below), and enclosed by yellow ellipses, detected only contamination linked to human sources (BacHum) alone. (Quantitative results presented in Supporting Information \#4).

The gradual increase in FIO flux moving downstream is also consistent with the spatial variation in specific electric conductance observed by Finn(2012), who noted a number of livestock access points and areas of concentrated (fresh) organic waste on the river between the headwaters and outlet, during the open season. Eyles et al.(2003) reported that direct deposition of manure to water courses has the 
capacity to overprint contributions from other sources. The conditions observed would explain the E.coli-dominated signature of all samples collected at this time. By contrast, the absence of livestock outdoors cannot explain either the fresh signatures observed in water samples collected during the closed period, or the lack of overall significant differences in the ranges of FIO fluxes with the open period.

Results of MST assist in explaining these discrepancies. Widespread bovine signatures in samples collected from across the catchment during open season are consistent with livestock dominating the FIO contributions at this time, with supplemental human contributions provided by the wastewater treatment plant, as observed at MK1 and MK6 further downstream. By contrast MST data suggest that the comparably fresh FIO contributions made to base flow during the closed season cannot be attributable to livestock, and, by inference, to livestock holding areas and associated waste storage facilities. The dominance of human Bacteroides (BacHum) signatures suggests contamination by human sewage. At points downstream of the Collon Wastewater Treatment Plant at least part of this load can be attributed to sewage derived from the town and would explain higher median Total Coliform and E.coli fluxes relative to the results of analyses of samples collected from monitoring points further upstream. By contrast, the occurrence of significant fluxes of human sewage-derived FIOs in this upper stretch is attributed to an alternative source, namely OSWWTSs.

Explanation of the detectable levels of human contamination upstream of the Collon WWTP discharge during the closed season, but not during the open season, requires consideration of hydrological conditions. OSWWTs systems are designed to discharge to the subsurface, where natural attenuation processes such as predation and inactivation reduce FIO levels in wastewater, and ideally should remove all pathogenic microorganisms (and associated FIOs) before reaching the water table Beal et al., 2005). Studies by Keegan et al.(2014) demonstrate that in relative low permeability Irish subsoils, significant attenuation can occur. However, Beal et al. (2005) stress that the degree of attenuation experienced strongly depends on the thickness of the unsaturated zone separating the infiltrating area, while the hydraulic gradient and subsoil saturated/unsaturated permeability determine capacity of the ground to accept infiltrating effluent. Investigations by Donohue et al.(2015) in comparable deposits to those encountered in the Mattock Catchment have noted that elevated water tables of perched groundwater can lead to effluent exfiltration in a setting where the OSWWTS is underlain by clayey till and a poorly productive bedrock aquifer. McCarthy et al. (2012) noted that in these settings it is common practice for property owners to install overflow pipes from OSWWTS percolation areas to open drains to prevent exfiltration.

Hydrograph data from the subsoil monitoring borehole close to the catchment outlet revealed a rise in groundwater level as the closed season progresses (Figure 2). The rise of approximately $20 \mathrm{~cm}$ is small, but may be sufficient to bring (regional and perched) water tables up to the base of OSWWTS percolation areas (as noted by Donohue et al., 2015)). Moreover Moe et al. (2010) report that groundwater fluctuations in Irish poorly productive aquifer systems generally increase from discharge points toward catchment divides. Consequently the range in water table fluctuation observed at the borehole is suspected to under represent the range operating more widely across the catchment. The development / expansion of water-logged areas across the catchment, as the closed season progressed, corresponds to periods of higher water table is consistent with these findings. This change in subsoil moisture content is accompanied by increased hydraulic connectivity in drains that facilitates delivery of effluent to the river.

The discharge of OSWWTS effluent to open drains that are hydraulically connected to the main river channel can thus explain the detection of significant fluxes of human sewage-derived microbiological contamination in surface water during those periods of the year when subsoil groundwater levels are high and the drain network across the Mattock Catchment is better connected. Conversely, the absence of detectable bovine signatures suggest that winter land use restrictions can be effective at preventing significant agriculturally-derived contaminants from impacting base flow water quality during the closed season. 


\section{Conclusions}

The results of this study highlight the capacity of organic wastes derived from human and agricultural sources to impact the quality of base flow in a water source destined for human consumption. In the case of the Mattock Catchment this has resulted in the application of drinking water treatment before delivery to consumers (and the costs that this entails). Despite the elevated levels of FIOs observed, findings further suggest that the source of these contaminants is not persistent throughout the year. Results of MST analyses show that winter farming restrictions can reduce, and possibly eliminate, the impact of agriculturally-derived organic wastes on the microbiological quality of base flow. Moreover, this further suggests that the measures can also be effective in preventing impacts from associated contaminants that may affect water status and water body ecological health, notably nutrients.

As a corollary to this conclusion, the results of the study indicate that the capacity of OSWWTS to affect surface water quality may be ephemeral, or more specifically a function of moisture conditions in receiving geological units. These findings indicate that the potential risk from microbiological contamination to surface water supplies can depend in part on transient hydrological conditions across a catchment. It is noteworthy that risks posed by sewage entails the added threat of species-specific (, notably human,) virus impacts to water quality, which are generally more difficult to remove in water treatment processes (and rarely monitored in microbiological sampling programs) ${ }^{3}$.

Overall, the results of this study highlight the temporal variation in pollution sources throughout the year at a catchment scale. At the same time the microbiological data collected, particularly when considered in conjunction with hydrological data provide useful information necessary to investigate the environmental mobility both chemical and microbiological contaminants in water bodies and to devise strategies to satisfy the requirements of the Water Framework Directive.

\section{Acknowledgements:}

This research was funded under the Irish Environmental Protection Agency's Science, Technology, Research and Innovation for the Environment (STRIVE) program. The Pathways Project (2007WQCD-S1)2007-2013 funded the research of all authors, apart from that of K.Kilroy and V.O'Flaherty, who were funded under Project\# 2012-W-MS-12 through the same EPA program. The STRIVE program was financed by the Irish Government under the National Development Plan 20072013, and administered by the Irish Environmental Protection Agency. The authors wish to express their gratitude to the Pathways Project Steering Committee for their contributions and advice in developing the Mattock Catchment monitoring program.

\section{References}

Alexander, R. B.; Boyer, E. W.; Smith, R. A.; Schwarz, G.E., Moore, R.B. The role of headwater streams in downstream water quality 2007, Journal of the American Water Resources Association, 43(1), 41-59

Archbold, M., Bruen, M., Deakin, J., Doody, D., Flynn, R., Kelly-Quinn, M., Misstear B. and Ofterdinger, U.. Contaminant movement and attenuation along pathways from the land surface to aquatic receptors - A Review. 2010, STRIVE Report 56 pp165, Wexford. ISBN978-1-84095-364-0. Arnscheidt, J.; Jordan, P.; Li, S.; McCormick, S.; McFaul, R.; McGrogan, H. J.; Neal., M.; Sims, J. T. Defining the sources of low-flow phosphorus transfers in complex catchments. 2007, Science of the. Total Environment, 382(1), 1-13.

Barrett, E., Kerr, C., Murphy, K., O'Sullivan, O., Ryan, C. A., Dempsey, E. M., ... \& Stanton, C. . The individual-specific and diverse nature of the preterm infant microbiota. 2013, Archives of Disease in Childhood-Fetal and Neonatal Edition, fetalneonatal-2012.

Beal, C. D., Gardner, E. A., \& Menzies, N. W. Process, performance, and pollution potential: A review of septic tank-soil absorption systems. 2005, Soil Research., 43(7), 781-802. 
Deakin, J. The role of the near surface pathways in the delivery of flow and contaminants to streams in Irish catchments. 2015, PhD thesis, Department of Civil, Structural and Environmental Engineering, Trinity College Dublin.

Deakin, J., Archbold, M., Orr, A., O'Brien, R., Maher, P., Thompson, J., Cocchiglia, L., Misstear, B., Kelly-Quinn, M., Ofterdinger, U. and Flynn, R. Pathways Project Final Report Volume 1: Field Investigation and Catchment Conceptual Models 2007-WQ-CD-1-S1. 2015, STRIVE Report. http://erc.epa.ie/safer/iso19115/display?isoID=196\#files.

Department of Agriculture, Food and the Marine. Explanatory handbook for good agricultural practice for the protection of waters regulations. 2014, pp 41, Irish Government Publications, Dublin. Donohue, S., McCarthy, V., Rafferty, P., Orr, A., \& Flynn, R. Geophysical and hydrogeological characterization of the impacts of on-site wastewater treatment discharge to groundwater in a poorly productive bedrock aquifer.2015, Science of the Total Environment, 523, 109-119.

Edwards, A.C., Kay, D., McDonald, A.T., Francis, C., Watkins, J., Wilkinson, J.R., Wyer, M.D. Farmyards, an overlooked source of highly contaminated runoff. 2008, Journal of Environmental Management. 87, 551-559.

Environmental Protection Agency. Drinking water report 2013. 2015, pp 48, Wexford ISBN 978-184095-573-6

European Commission (2000) Directive 2000/60/EC of the European Parliament and of the Council of 23 October 2000 establishing a framework for Community action in the field of water policy .Official Journal L 327 , 22/12/2000 P. 0001 - 0073

European Commission (1991) Council Directive 91/676/EEC of 12 December 1991 concerning the protection of waters against pollution caused by nitrates from agricultural sources. Official Journal $\mathrm{L}$ 375, 31/12/1991 P. $0001-0008$

Eyles, R., Niyogi, D., Townsend, C., Benwell, G., \& Weinstein, P. Spatial and Temporal Patterns of Contamination Underlying Public Health Risk in the Taieri River, New Zealand. 2003, Journal of Environmental Quality, 32(5), 1820-1828.

Finn., J. Comparison of surface water quality variation in two poorly productive catchments. 2012, MSc Thesis, The Queen's University of Belfast.

Government of Ireland. Statutory Instrument 31 of 2014 - European Union Regulations (Good Agricultural practice for protection of waters)). 2014, pp 50, Government Publications, Dublin. Herschy, R. W. Flow measurement. Hydrometry principles and practices. 1999, Edited by RW Herschy. John Wiley and Sons Ltd., Chichester, UK, 9-84.

Kay, D., Anthony, S., Crowther, Chambers, B.J., Nicholson, F.A., Chadwick, D., Stapleton, C.M. and Wyer, M.D. Microbial water pollution: a screening tool for initial catchment-scale assessment and source apportionment. 2010, Science of the Total Environment 408 (23): 5649-5656.

Keegan, M., Kilroy, K., Nolan, D., Dubber, D., Johnston, P.M,Misstear, B.D.R., O'Flaherty, V., Barrett, M. and Gill., L.W. Assessment of the impact of traditional septic tank soakaway systems on water quality in Ireland. 2014, Water Science \& Technology, 70,(4): 634-641.

Kildare, B. J.; Leutenegger, C. M.; McSwain, B. S.; Bambic, D. G.; Rajal, V. B.; Wuertz, S.. 16S rRNA-based assays for quantitative detection of universal, human-, cow-, and dog-specific fecal Bacteroidales: a Bayesian approach. 2007, Water Research, 41(16), 3701-3715.

Mara, D., \& Horan, N. J. (Eds.) Handbook of water and wastewater microbiology. 2003, Academic press.

Moe., H., Craig, M., Daly, D. Poorly productive aquifers. Monitoring installations and conceptual understandings. Environmental Protection Agency Dublin. 2010, Pp36,

http://www.epa.ie/pubs/reports/water/ground/ppa/EPA\%20Poorly\%20Productive\%20Aquifers\%20Su mmary\%20Report.pdf

McCarthy, V., Flynn, R., Orr, A., Rafferty, P., Minet, E., Meehan, R., Archbold, M., Linnane, S. A Field study assessing the impact of on-site wastewater treatment systems (OSWTS) on surface water in a Co. Monaghan Catchment. 2012, Centre for freshwater studies Dundalk Institute of Technology. Pp135, Dundalk.

https://www.academia.edu/1497889/A field study assessing the impact of onsite wastewater trea tement_systems_OSWTS_on_surface_water_in_the_Milltown_Lake_catchment_Co._Monaghan 
Noble, R. T., Griffith, J. F., Blackwood, A. D., Fuhrman, J. A., Gregory, J. B., Hernandez, X., Liang, X., Bera, A. A. \& Schiff, K. (2006). Multitiered Approach Using Quantitative PCR To Track Sources of Fecal Pollution Affecting Santa Monica Bay, California. Applied and Environmental Microbiology, 73(8), 1604-1612.

Pepper, I. L., Gerba, C. P., Gentry, T. J., \& Maier, R. M. (Eds.). Environmental microbiology. 2011, Academic Press.

Seurinck, S., Verstraete, W., \& Siciliano, S. D. Microbial source tracking for identification of fecal pollution. 2005. Rev. Environmental Science Biology/Technology, 4(1-2), 19-37.

UK Environment Agency (2014) Standing Committee of Analysts (SCA) Blue Books. 2014.

https://www.gov.uk/government/publications/standing-committee-of-analysts-sca-blue-books

Whyte, P., McGill, K., Cowley, D., Madden, R. H., Moran, L., Scates, P.; Cormican, M. Occurrence of Campylobacter in retail foods in Ireland.2004, International Journal of Food Microbiology, 95(2), 111-118. 


\section{Supporting Information \#1}

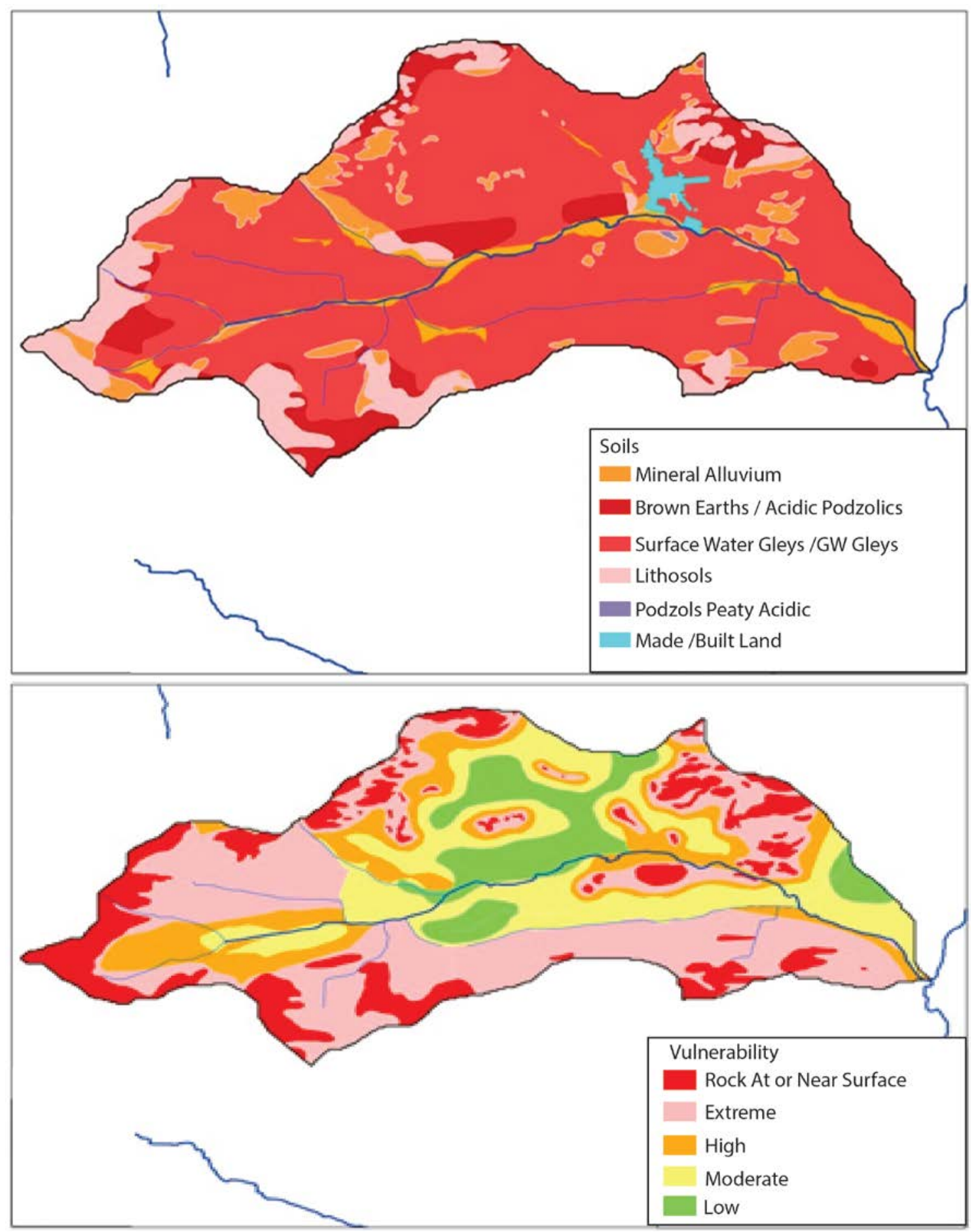

Figure: Maps of soil type (above) and subsoil vulnerability (below). Soil types, apart from alluvium, built land and lithosols, are derived from low permeability glacial till parent material. Vulnerability is a function of subsoil thickness and permeability and reflects subsoil thickness in areas of comparable subsoil permeability.

\section{Supporting Information \#2}

Table Oligonucleotide primers and probes used in qPCR assays to detect Bacteroidales 16S rRNA genes 


\begin{tabular}{cccc}
\hline Human Bacteroidales & & & size (bp) \\
& BacHum-160f & TGAGTTCACATGTCCGCATGA & \\
& BacHum-241r & CGTTACCCCGCCTACTATCTAATG & \\
& *BacHum-193p & 6-FAM- & \\
Ruminant & & TCCGGTAGACGATGGGGATGCGTT- \\
Bacteroidales & BacBov- & CCAACYTTCCCGWTACTC & 177 \\
& CF128f & GGACCGTGTCTCAGTTCCAGTG & \\
& BacBov-305r & 6-FAM- & \\
& *BacBov-257p & TAGGGGTTCTGAGAGGAAGGTCCCC- & \\
& & TAMRA \\
\hline
\end{tabular}

\section{Supporting Information \#3}

Trilinear plots of relative concentrations of selected fecal indicator organisms for open (above) and closed season sampling (below), Glen Burn Catchment, Co. Down, Northern Ireland. This catchment is underlain by poorly productive Silurian Bedrock comparable to that encountered in the Mattock Headwaters and approaching the river's outlet. Signatures for summer sampling reveal fresh waste associated with direct deposition of organic wastes by grazing cattle. By contrast, signatures during winter monitoring reflect more aged waste, due in part to a lower OSWTS-derived pollutant load. 
Relative concentrations of Selected Indicator Bacteria, Glen Burn Surface Water, Summer 2012

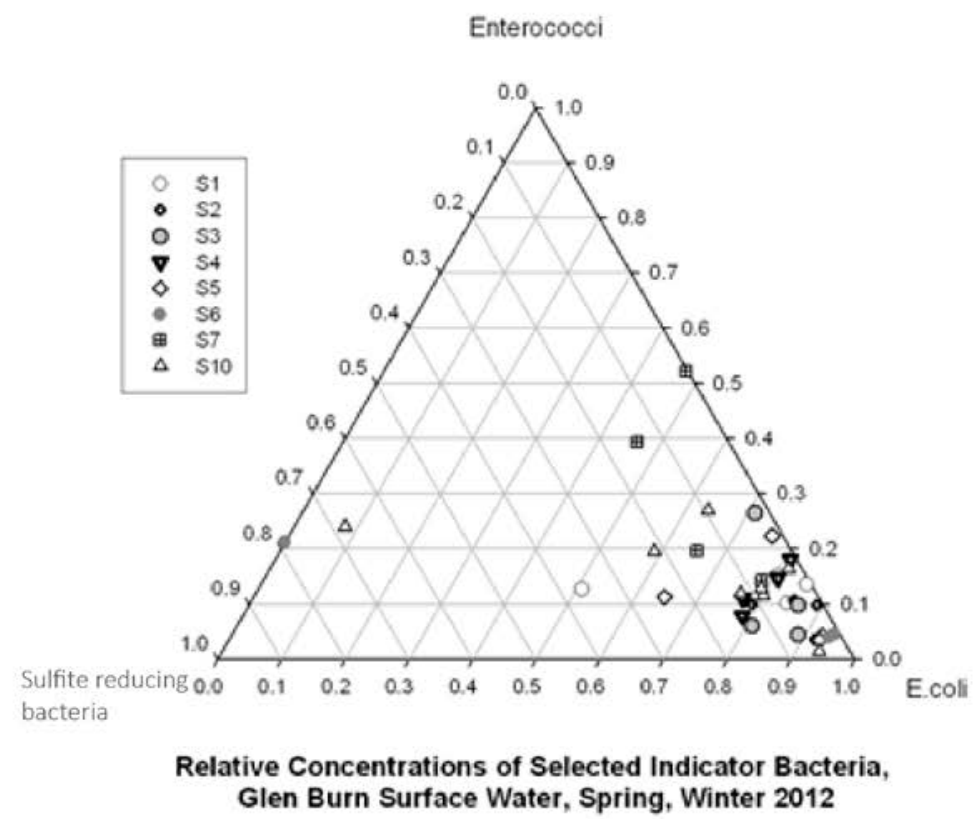

Enterococci

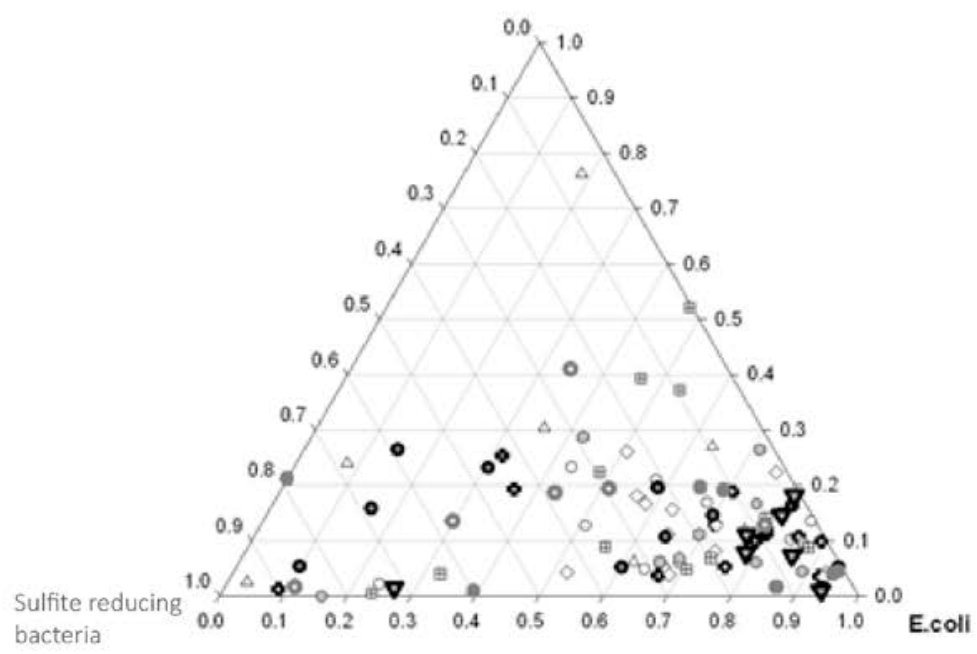

Supporting Information \#4. 

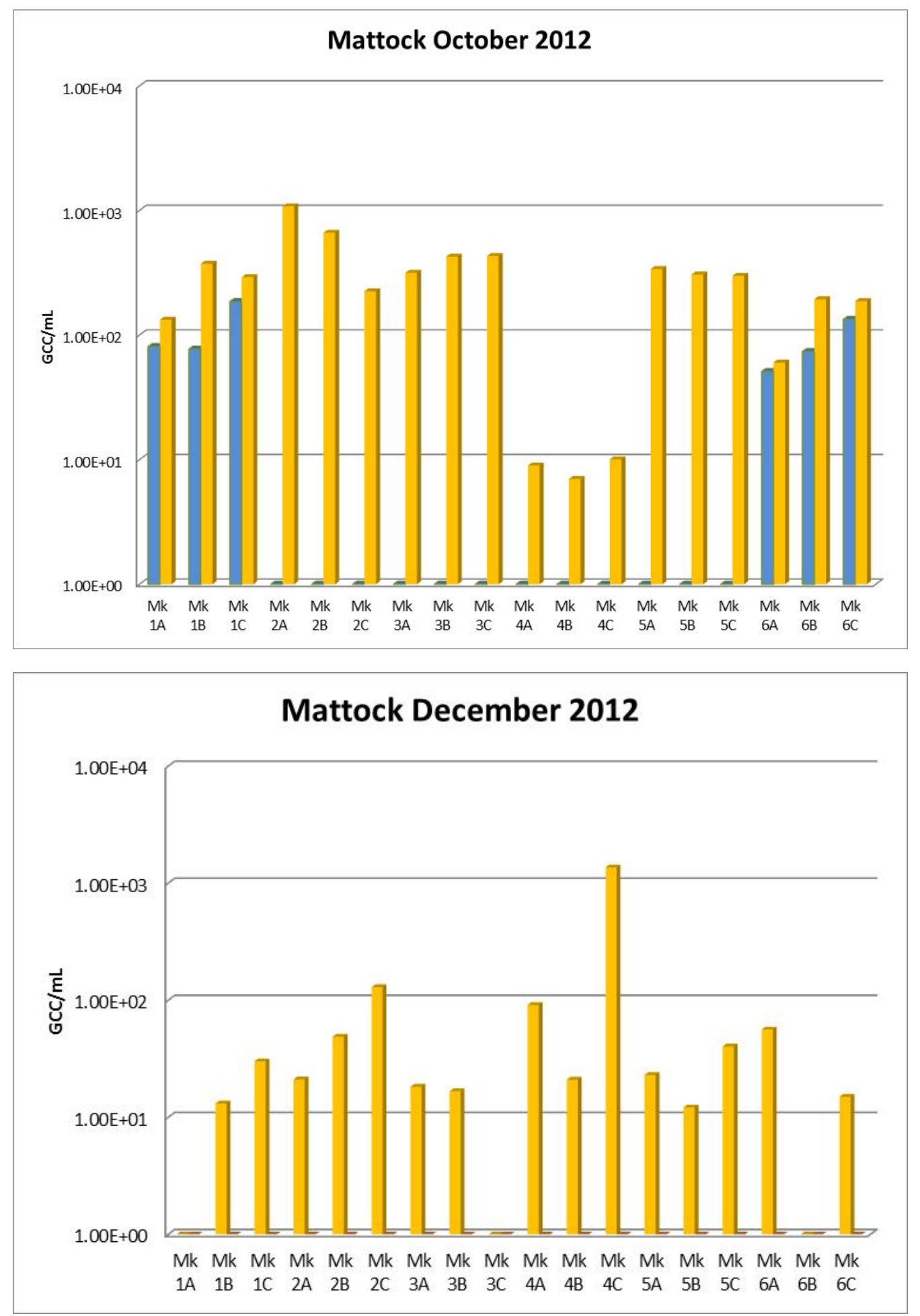

Figure: Human-specific (BacHum) and Bovine-specific (BacBov) Bacteroidales bacteria real-time PCR results for the Mattock river samples retrieved for monitoring points (Mk-1 to Mk-6) in October 2012 (above) and December 2012 (below). Results are shown as gene copy concentrations per milliliter $(\mathrm{GCC} / \mathrm{mL})$ for each triplicate sample $(\mathrm{A}, \mathrm{B}, \mathrm{C})$. Human: Yellow; Bovine: Blue. 